\title{
In situ localization of three cDNA sequences associated with the later stages of aposporic embryo sac development of Brachiaria brizantha
}

\author{
E. R. Alves ${ }^{1,2}$, V. T. C. Carneiro ${ }^{1,2}$, and D. M. A. Dusi ${ }^{2, *}$ \\ ${ }^{1}$ Departamento de Biologia Celular, Universidade de Brasília, Brasília, Distrito Federal \\ ${ }^{2}$ Embrapa Recursos Genéticos e Biotecnologia, Empresa Brasileira de Pesquisa Agropecuária, Brasília, Distrito Federal
}

Received September 12, 2006; accepted November 7, 2006; published online July 3, 2007

(C) Springer-Verlag 2007

\begin{abstract}
Summary. Brachiaria brizantha is a forage grass of African origin, highly cultivated in the Brazilian tropics for beef cattle production. We have analyzed the temporal and spatial expression of cDNA sequences by in situ hybridization in ovaries of apomictic and sexual plants. The studied sequences share molecular identity with myosin, aquaporin, and mitogen-activated protein kinase and were named BbrizMYO, BbrizAQP, and BbrizMAPK, respectively. BbrizMYO was expressed in apomictic and sexual embryo sacs, but somewhat later in the Polygonum type embryo sacs of sexual plants. BbrizAQP and BbrizMAPK transcripts were restricted to the Panicum type embryo sacs of apomictic plants; BbrizMAPK, in synergids; and BbrizAQP, also in different ovular cells during development. The common feature that arose from the analysis of the expression patterns of these three sequences was significant expression in the synergids. Their putative role in the maturation of Panicum type embryo sacs of apomictic plants and embryo development is discussed in view of the characteristics of apomictic reproduction.
\end{abstract}

Keywords: Apomixis; Brachiaria brizantha; Differentially expressed cDNA; In situ hybridization; Ovule.

\section{Introduction}

Reproduction in angiosperms is generally achieved by the double fertilization of the reduced embryo sac (ES). While the fusion of one sperm cell with the egg cell leads to the formation of an embryo, the fusion of the other sperm cell with the diploid central cell nucleus gives rise to a triploid endosperm. Alternatively, more than 300 species of 35 families of angiosperms (Hanna and Bashaw 1987, Carman 1997) reproduce by apomixis and embryos develop autonomously; this is, independently of egg cell fertilization.

\footnotetext{
* Correspondence and reprints: Embrapa Recursos Genéticos e Biotecnologia, Parque Estação Biológica, Avenida W 5 Norte (Final), 70770900 Brasília, DF, Brazil.

E-mail: diva@cenargen.embrapa.br
}

The progeny is identical to the mother plant. Apomixis is described as sporophytic or gametophytic (Nogler 1984). In sporophytic apomixis, or adventitious embryony, embryos are formed directly from unreduced nucellus or inner integument cells. In gametophytic apomixis, meiosis is altered or does not happen, and an unreduced ES is formed (Asker and Jerling 1992, Nogler 1994). Gametophytic apomixis is named diplospory when the unreduced ES originates from the megaspore mother cell (MMC) or apospory when it comes from nucellus cells called the apospore initials (AI).

The genus Brachiaria is a member of the family Poaceae. Members of this genus, of African origin, are now considered to be the most important forage for tropical beef cattle production. Introduced to Brazil in 1952 (Serrão and Simão Neto 1971), the agronomic characteristics of accessions from Brachiaria decumbens and B. brizantha are very suited to the climate and soil conditions, and in 1996 it was estimated that an area greater than 70 million hectares was used to cultivate Brachiaria species (Fisher and Kerridge 1996). Inheritance analyses carried out on different species suggested that the apomictic character is controlled by a single dominant gene (Miles et al. 1996).

Sexual plants of Brachiaria species have a common pathway that leads to the formation of an eight-nucleated Polygonum type ES. In this case, meiosis of the MMC produces four reduced megaspores. One of them survives and undergoes mitosis to form an ES containing seven cells: three antipodal cells at the chalazal extremity, a central cell with two nuclei, two synergids, and one egg cell at the micropylar pole forming the egg apparatus (Dusi and Willemse 1999b, Araujo et al. 2000). 
Apomixis in Brachiaria species is of the aposporous type (Lutts et al. 1994; do Valle and Savidan 1996; Dusi and Willemse 1999a, b; Araujo et al. 2000). During ovule development, a number of nucellus cells differentiate to form the AI. These cells enter mitosis directly to form a Panicum type ES, with four cells situated in the micropyle. The unreduced egg cell develops autonomously, but the polar nucleus is fertilized by a male gamete (Alves et al. 2001) to generate the endosperm (Ngendahayo 1988).

Analysis of ES structure and ploidy level of the plants of Brachiaria species from the Embrapa germplasm collection indicates that sexual reproduction is rare (do Valle 1986, do Valle and Savidan 1996, Penteado et al. 2000). Only one among 275 accessions of $B$. brizantha shows an ES of the Polygonum type (do Valle and Savidan 1996). In all the other accessions, both Panicum and Polygonum type ES coexist in different ratios within the same ovule, a characteristic of facultative apomixis. Brachiaria brizantha cv. Marandu is one of the most apomictic plants, with 98\% of the ES being of the Panicum type (do Valle and Savidan 1996, Araujo et al. 2000).

In order to detect the genes associated with apomixis, molecular analyses of ovary development have been carried out in natural apomicts, such as Pennisetum ciliare (Vielle-Calzada et al. 1996), Paspalum notatum (Pessino et al. 2001), Panicum maximum (Chen et al. 1999, 2005), Poa pratensis (Albertini et al. 2004, 2005), and Brachiaria species (Leblanc et al. 1997, Dusi 2001, Rodrigues et al. 2003). In $B$. brizantha, cDNAs that are differentially expressed at megasporogenesis and megagametogenesis have been identified in the ovaries of sexual and apomictic plants by differential-display PCR (Rodrigues et al. 2003).

Here we report the temporal and spatial expression pattern of three cDNA sequences, BbrizMYO, BbrizAQP, and BbrizMAPK, with molecular identity to myosin, aquaporin, and mitogen-activated protein kinase (MAPK), respectively, during the ovary development of apomictic and sexual B. brizantha plants grown in natural conditions. Our data confirm the differential expression pattern of the sequences in sexual and apomictic development, and show the timing of cellular expression. These sequences may play a key role in the ES development of apomictic plants and may be involved in pollination and fertilization processes.

\section{Material and methods}

\section{Plant material}

Two accessions of $B$. brizantha cultivated in the field at Embrapa Genetic Resources and Biotechnology were used: BRA 002747, a diploid
$(2 \mathrm{n}=2 \mathrm{x}=18)$ sexual, and BRA 00591, a tetraploid $(2 \mathrm{n}=4 \mathrm{x}=36)$ facultative apomictic named $B$. brizantha (A. Rich) Stapf cv. Marandu.

\section{Tissue preparation}

Pistils were removed from spikelets and fixed for $1 \mathrm{~h}$ under vacuum at room temperature in $4 \%$ paraformaldehyde, $0.25 \%$ glutaraldehyde, and $0.1 \mathrm{M} \mathrm{NaCl}$ in $0.01 \mathrm{M}$ phosphate buffer, $\mathrm{pH}$ 7.2. The fixative was refreshed, and after a further $3 \mathrm{~h}$ without vacuum, the samples were washed in $0.001 \mathrm{M}$ phosphate buffer at $\mathrm{pH} 7.2$ and then dehydrated through an ethanol series. Samples were then transferred to butyl-methyl methacrylate (BMM) in a series of ethanol-BMM washes and embedded in BMM at $4{ }^{\circ} \mathrm{C}$ for at least $4 \mathrm{~h}$. The samples were placed in plastic capsules containing BMM mixture for polymerization under UV irradiation for $48 \mathrm{~h}$ at $-20{ }^{\circ} \mathrm{C}$. Semithin sections, 3-3.5 $\mu \mathrm{m}$, were placed on drops of water on glass slides, stretched with chloroform vapor, and dried on a hot plate at $60{ }^{\circ} \mathrm{C}$ for $1 \mathrm{~h}$. BMM was removed by two washes in $100 \%$ acetone, one wash in acetone-water $(1: 1, \mathrm{v} / \mathrm{v})$, and a final wash in water. Before hybridization, some sections were stained with acridine orange and examined under UV light to check RNA integrity.

\section{Probe preparation}

The RNA probe was synthesized using the digoxigenin RNA labeling kit (Roche) according to the manufacturer's instructions. Digoxigenin-labeled antisense and sense RNA probes were generated by direct in vitro transcription of the template. Three clones that were generated by differential-display PCR and previously cloned into pGEM-T Easy Vector System I (Invitrogen Life Technologies) (Rodrigues et al. 2003) were used as template: clone 18 (281 bp), named BbrizMYO; clone 30 (303 bp), named BbrizMAPK; and clone 34 (253 bp), named BbrizAQP. Vectors with BbrizMYO and BbrizMAPK were linearized by digestion with SpeI or NcoI, and the vector containing BbrizAQP was digested with SalI or $N c o$ I to generate $5^{\prime}$ protruding ends. T7 polymerase was used to synthesize sense probes, and SP6 polymerase generated antisense probes. RNA probes were precipitated in $3 \mathrm{M}$ sodium acetate, $\mathrm{pH} 5.5$, in $100 \%$ ethanol $(1: 10, \mathrm{v} / \mathrm{v})$, for $2.5 \mathrm{~h}$ at $-20{ }^{\circ} \mathrm{C}$. After centrifugation, the pellets were briefly washed in $70 \%$ ethanol, air dried and resuspended in $25 \mu \mathrm{l}$ of diethylpyrocarbonate-treated water. An estimation of probe quantity was performed by comparing the signal intensity to $100 \mathrm{ng}$ and $10 \mathrm{ng}$ labeled reference RNAs (Roche) simultaneously blotted onto a nylon membrane.

\section{Hybridization and posthybridization reactions}

Sections were hybridized with $60 \mathrm{ng}$ of the digoxigenin-labeled RNA probe, diluted in $100 \mu \mathrm{l}$ of hybridization buffer ( $50 \%$ formamide, $1 \times$ Denhardt's solution, $25 \mathrm{ng}$ of tRNA per $\mu \mathrm{l}, 300 \mathrm{mM} \mathrm{NaCl}, 10 \%$ dextran sulfate, $10 \mathrm{mM}$ Tris- $\mathrm{HCl}$ [pH 7.5], and $1 \mathrm{mM}$ EDTA [pH 8.0] in water). Hybridization took place overnight inside a humid chamber in the dark at $42{ }^{\circ} \mathrm{C}$. Subsequently, the sections were washed at $42{ }^{\circ} \mathrm{C}$ in $4 \times, 2 \times$, $1 \times$, and $0.5 \times \mathrm{SSC}(4 \times \mathrm{SSC}$ is $0.6 \mathrm{M} \mathrm{NaCl}$ plus $0.06 \mathrm{M}$ sodium citrate, $\mathrm{pH} 7.0$ ) for $30 \mathrm{~min}$ each. Sections were blocked for $30 \mathrm{~min}$ in $2 \%$ bovine serum albumin in buffer $1(0.15 \mathrm{M} \mathrm{NaCl}$ in $0.1 \mathrm{M}$ Tris- $\mathrm{HCl}, \mathrm{pH} 7.5)$. Slides were incubated with anti-digoxigenin-AP Fab fragments (Roche) diluted $1: 1000$ in buffer 1 for $2 \mathrm{~h}$ and then washed twice for $15 \mathrm{~min}$ in buffer 1 to remove unbound antibodies. Sections were transferred to detection buffer $3(0.1 \mathrm{M}$ Tris- $\mathrm{HCl}, \mathrm{pH} 7.5$, containing $0.1 \mathrm{M} \mathrm{NaCl}$ and $0.05 \mathrm{M} \mathrm{MgCl}_{2}$; final $\mathrm{pH}$ adjusted to 9.5 ) for $5 \mathrm{~min}$ before staining in $1 \mathrm{ml}$ of detection buffer 3 supplemented with $4.5 \mu \mathrm{l}$ of nitro-blue tetrazolium chloride $(50 \mathrm{mg} / \mathrm{ml})$ and $4.5 \mu \mathrm{l}$ of 5-bromo-4-chloro-3-indolyl phosphate $(50 \mathrm{mg} / \mathrm{ml})$. The staining reaction was stopped by washing slides in detection buffer 4 (0.01 M Tris-HCl, pH 8.0, containing 1 mM EDTA), and the sections were mounted in Permount SP15-500 (Fisher Scientific). Hybridized sections were observed with a Zeiss Axiophot light micro- 
scope. For both sexual and apomictic accessions of B. brizantha, all stages of female gametophyte development were simultaneously hybridized with a sense and an antisense probe.

\section{Results}

In order to assist the analysis of the in situ hybridization results, $B$. brizantha ovule development is schematized in Fig. 1 on the basis of a careful study of structural comparison between apomictic and sexual plants of $B$. brizantha (Araujo et al. 2000) and B. decumbens (Dusi and Willemse $1999 \mathrm{a}, \mathrm{b})$. In sexual B. brizantha, the MMC enters meiosis to form a line of four reduced megaspores. Three of them degenerate, while the chalazal one survives to form the functional megaspore. After three successive mitoses followed by cellularization, a Polygonum type ES is formed. During maturation, the two polar nuclei fuse, forming one diploid nucleus. As in other grasses, the antipodal cells proliferate to a total of 6 to 9 cells. Double fertilization leads to the formation of an embryo and an endosperm. In apomictic B. brizantha, initiation of ES development is similar to that of the sexual plant; an MMC undergoes meiosis to form four megaspores. In the apomict, not only three but all megaspores degenerate, and at the same time, some nucellus cells, the AI, enlarge. These AI undergo two mitoses to form a four-nucleated coenocyte (CO) whose nuclei are all positioned at the same pole. After cellularization, unreduced ES of the Panicum type are formed, mostly containing four cells. The absence of antipodal cells and the unreduced nature of the cells are characteristic of this type of ES. Because more than one AI can develop, more than one ES can be formed. While embryos develop autonomously, sometimes even before pollination, fertilization of the central cell is necessary to form an endosperm (Alves et al. 2001). If the chalazal megaspore survives, an ES of the Polygonum type can be found alone or next to the aposporic ES. In B. brizantha cv. Marandu, this was found in only $2 \%$ of the ovules (do Valle 1986, Araujo et al. 2000).

Good preservation of RNA was essential for the hybridization experiments and was checked by staining some

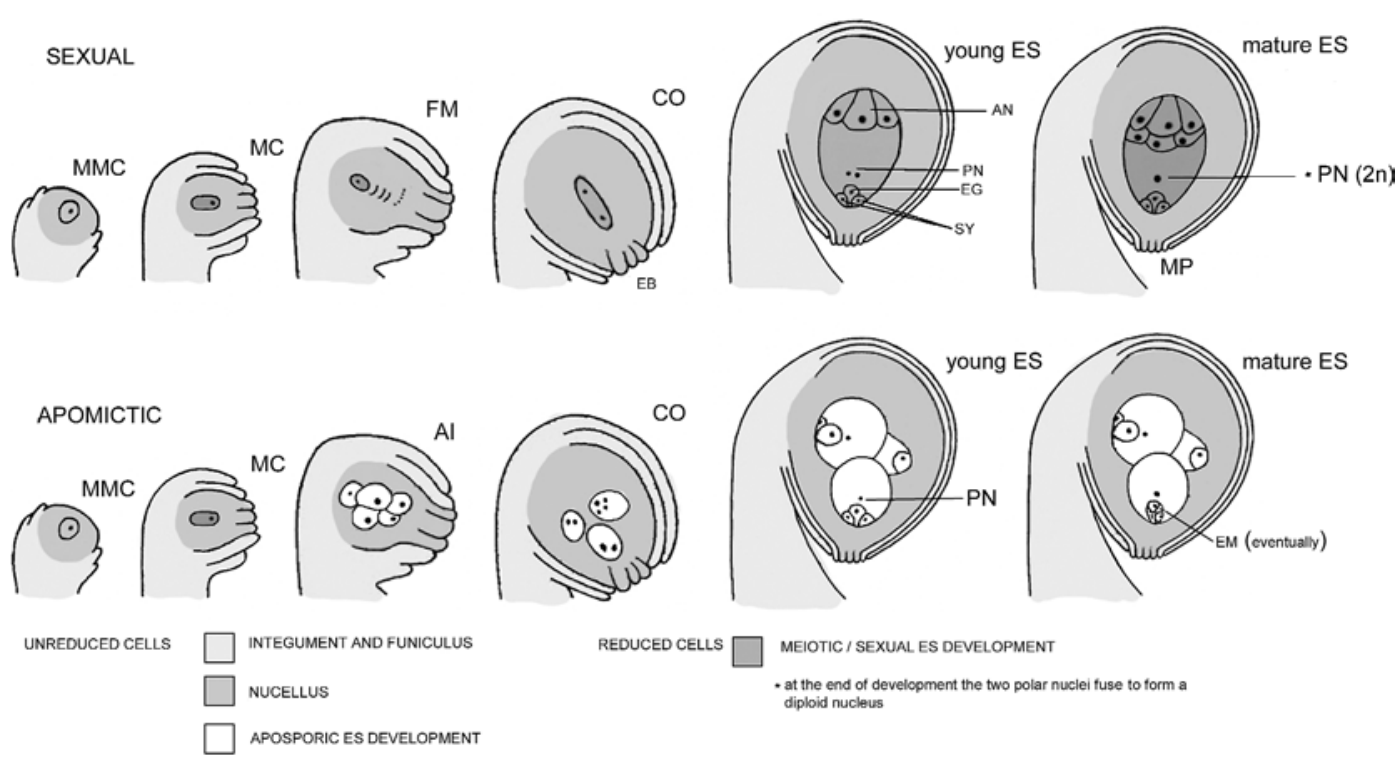

Fig. 1. Schematic representation of sexual and apomictic B. brizantha ovule development. In sexual B. brizantha, the archespore cell differentiates and enlarges to function as an MMC. This cell enters meiosis (meiocyte, $M C$ ) to form four reduced megaspores. Three of them degenerate, and the chalazal one survives (functional megaspore, $F M$ ). This functional megaspore undergoes three successive mitoses to form a two-, four-, and eight-nucleated $\mathrm{CO}$ with nuclei distributed equally in both chalazal and micropylar poles (embellum cells, EB). Then a cellularized young Polygonum type ES is formed, with seven cells containing eight haploid nuclei: at the chalazal pole three antipodal cells ( $A N)$, at the micropylar pole two synergids (SY) and one egg cell $(E G)$, and one central cell with two polar nuclei $(P N)$. Following cellularization, the antipodal cells proliferate to a number of 6 to 9 , and the two polar nuclei $(P N)$ fuse to form a diploid nucleus at the mature ES (micropyle, $M P$ ). ES development in the apomictic $B$. brizantha initiates as in the sexual plant. An MMC undergoes meiosis to form four megaspores. The four megaspores degenerate at the same time that some nucellus cells, the AI, enlarge. These cells undergo two mitoses to form two- and four-nucleated CO with nuclei positioned at the same pole. After cellularization, aposporic Panicum type ES are formed, containing four cells: two synergids, one egg cell, and one central cell with one polar nucleus $(P N)$. Eventually, before anthesis, embryos $(E M)$ can develop autonomously. In apomictic plants, more than one ES can develop in one ovule, which does not necessarily contain four cells. Modified from Dusi and Willemse (1999a) 
sections with acridine orange. After staining, RNA fluoresces orange under UV light, while DNA fluoresces green. RNA was well preserved in the cytoplasm, as well as in the nucleolus of the ovular cells of the sexual and apomictic plants, as could be seen by the strong RNA staining (see Fig. 3a).

Using a digoxigenin-labeled probe and nitro-blue tetrazolium chloride plus 5-bromo-4-chloro-3-indolyl phosphate, the RNA was marked by a blue-purple color. Sense probes of all clones were hybridized to establish the ac- ceptable background (see Figs. $3 \mathrm{~h}$ and $4 \mathrm{~d}$, g) and they provided good negative controls.

Results of in situ hybridization of BbrizMYO, BbrizAQP, and BbrizMAPK are schematized in Fig. 2.

In apomicts, BbrizMYO showed no hybridization in ovules containing an MMC (Fig. 3b), within the detection limit of our method. The signal in the nucellus cells gradually increased concurrent with a progression in development from ovules with a meiocyte (MC) to mature ES, but no signal was observed in the embellum cells in ovules

\section{BbrizMYO}<smiles>c1ccccc1</smiles><smiles>Cc1ccccc1</smiles>
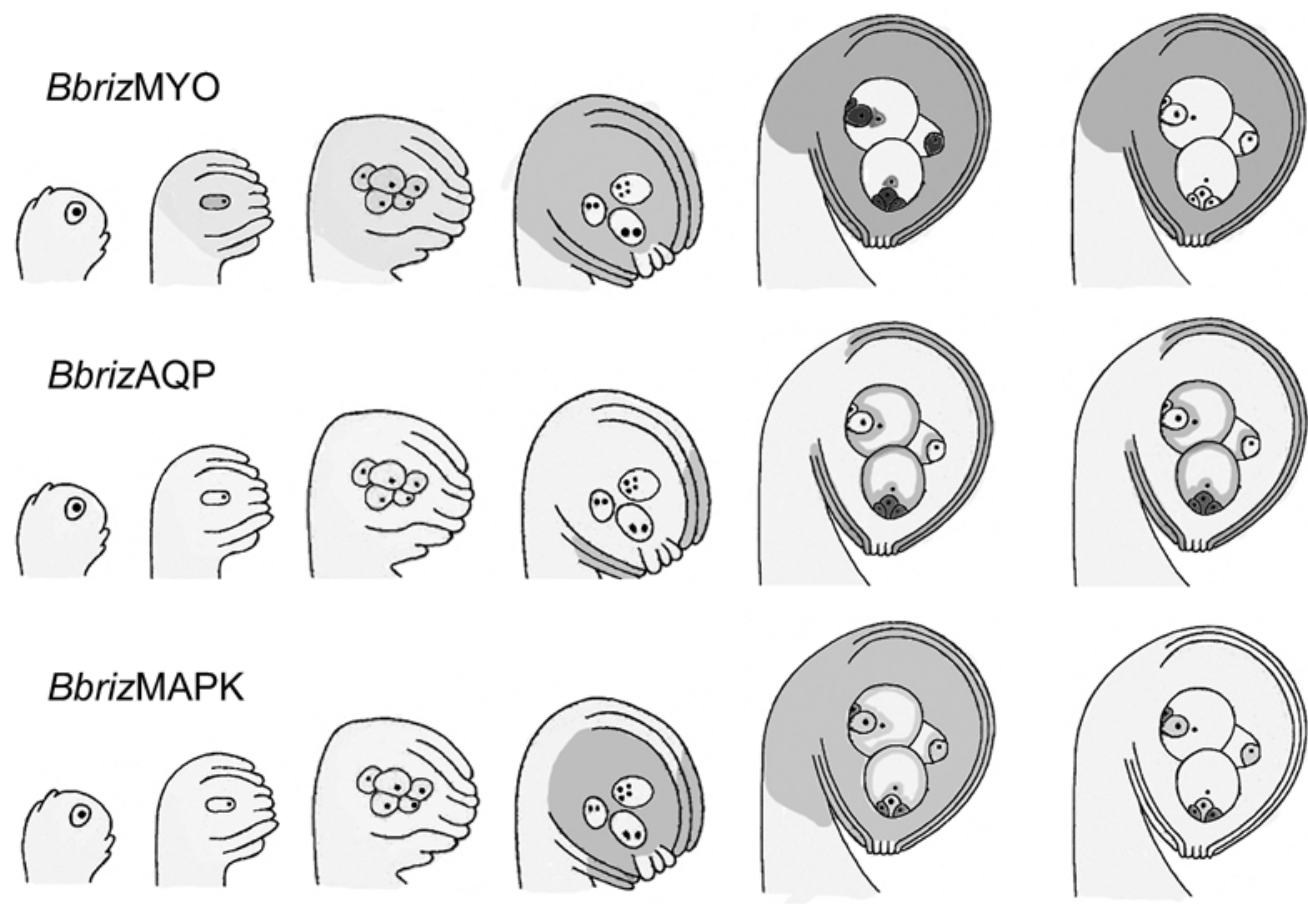

A

B

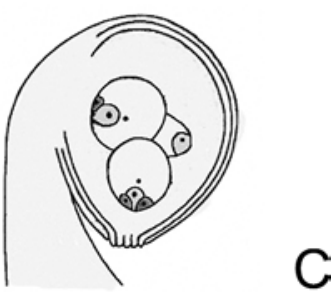

Fig. 2 A-C. Schematic representation of the expression of BbrizMYO, BbrizAQP, and BbrizMAPK during ovule development in apomictic B. brizantha. The darker the color, the greater the expression. A In the nucellus cells, there is an increase in the level of $B b r i z M Y O$ transcript during ovule maturation. In the ES cells, there is a modulation of transcription during ovule development. The expression is particularly notable in the MC and young ES, mainly on the synergids and egg cell. B The BbrizAQP transcript was not detectable in ovules that contain an MMC, MC, or AI. At CO, signal was observed in the integuments. In the young and mature ES, the central cell is marked. A stronger hybridization signal was noted in cells of the egg apparatus. C BbrizMAPK transcripts can be seen in the nucellus of ovules having a $\mathrm{CO}$ and their signal increases in the young ES. A strong hybridization signal was noted in the synergids of mature ES. In ES collected during anthesis and $48 \mathrm{~h}$ after pollination, transcripts could no longer be observed, within the detection limit of the method used

Fig. 3. Detection of BbrizMYO expression by in situ localization in semithin sections of ovules from apomictic (a-h) and sexual (i-m) B. brizantha plants. a Acridine orange staining for RNA (orange), showing MC of an ovule surrounded by nucellus $(N)$; bar: $4.5 \mu \mathrm{m}$. b No hybridization signal was observed in either the MMC or in the nucellus $(N)$; bar: $4.6 \mu \mathrm{m}$. c Same ovule as shown in a, a weak but notable signal can be observed in the MC and nucellus $(N)$; bar: $6 \mu \mathrm{m}$. d AI surrounded by nucellus $(N)$ showing a very weak label; bar: $4.7 \mu \mathrm{m}$. e An aposporic CO, without hybridization signal, beside an AI and enclosed by nucellus $(N)$ showing weak hybridization; bar: $5.3 \mu \mathrm{m}$. f Micropylar side of an ovule with a young aposporic ES showing one synergid cell $(S Y)$ without label, an egg cell $(E C)$ and part of the polar nucleus $(P N)$ marked strongly; bar: $3.6 \mu$ m. g Aposporic mature ES hybridized with antisense probe with label in the nucellus $(N)$, while no hybridization signal was detected in the central cell $(C C)$ or the synergids (SY) under our experimental conditions; bar: $7.3 \mu \mathrm{m}$. h No signal above background was detected in aposporic mature ES after hybridization with the sense probe; bar: $6.0 \mu \mathrm{m}$. i-m Ovules of sexual plants. i-k No signal was observed in the MMC (i) or MC or nucellus $(N)(\mathbf{j})$ or in the CO surrounded by nucellus $(N)(\mathbf{k})$. Bar: i, $3.3 \mu \mathrm{m} ; \mathrm{j}, 5.3 \mu \mathrm{m} ; \mathrm{k}, 4.7 \mu \mathrm{m}$. I Ovule with a mature meiotic ES with label in the nucellus $(N)$, antipodals $(A)$, and egg apparatus $(E A)$; bar: $6 \mu \mathrm{m}$. $\mathbf{m}$ Closer view of the micropylar region of the same section as in $\mathbf{I}$ with label in the nucellus $(N)$ and one of the synergids $\left(S Y^{*}\right)$; no signal was detectable in the other synergid $(S Y)$, filiform apparatus $(F A)$ and embellum cells $(E M)$; bar: $4.9 \mu \mathrm{m}$ 

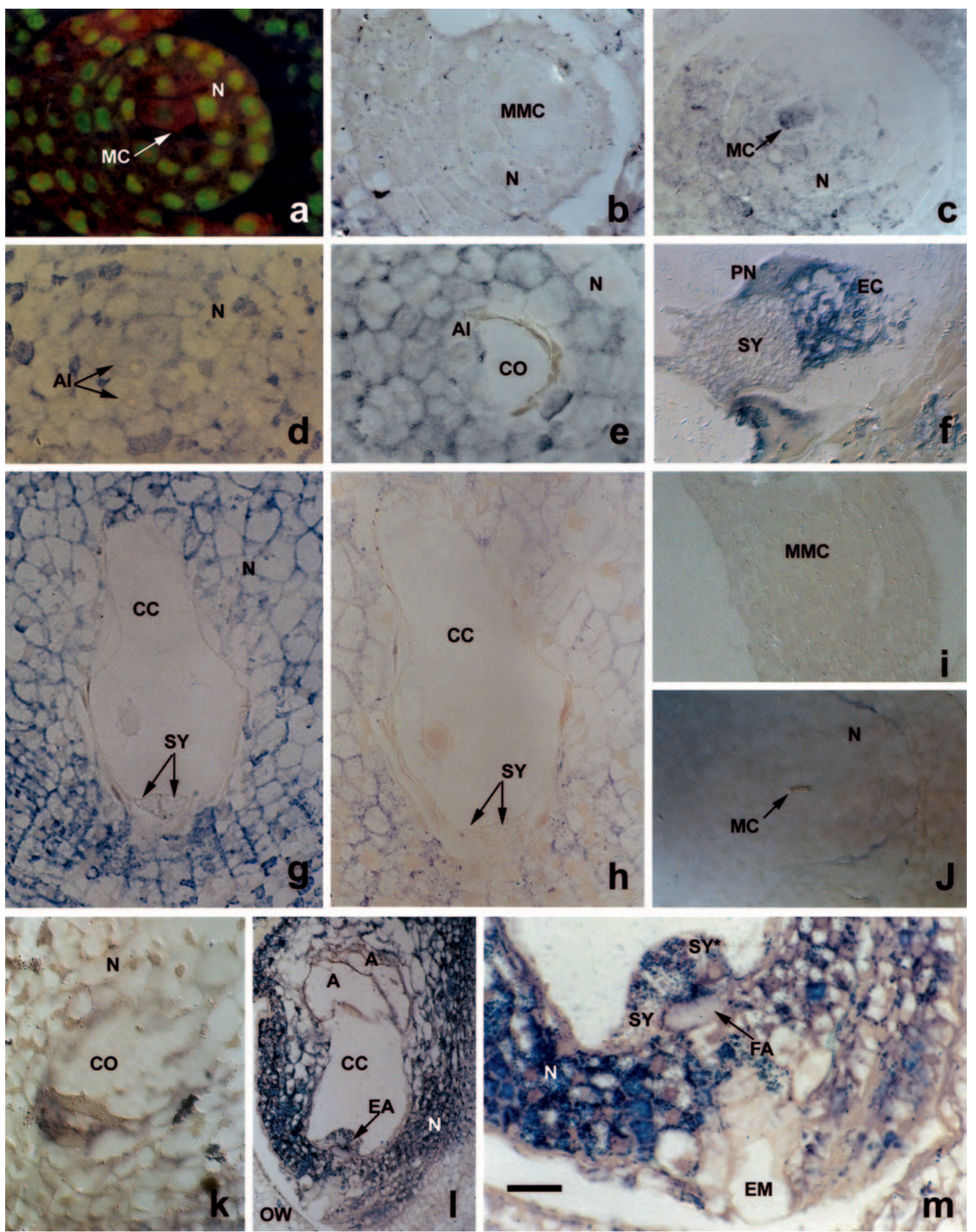

EM 
with a $\mathrm{CO}$ and mature ES. Signal was observed in the MC (Fig. 3c) but was very weak or absent in the AI (Fig. 3d). No signal was observed in the $\mathrm{CO}$, although the cells of the nucellus showed some weak hybridization (Fig. 3e). Just after cellularization, a very strong signal was observed in all cells, including the egg cell apparatus, the central
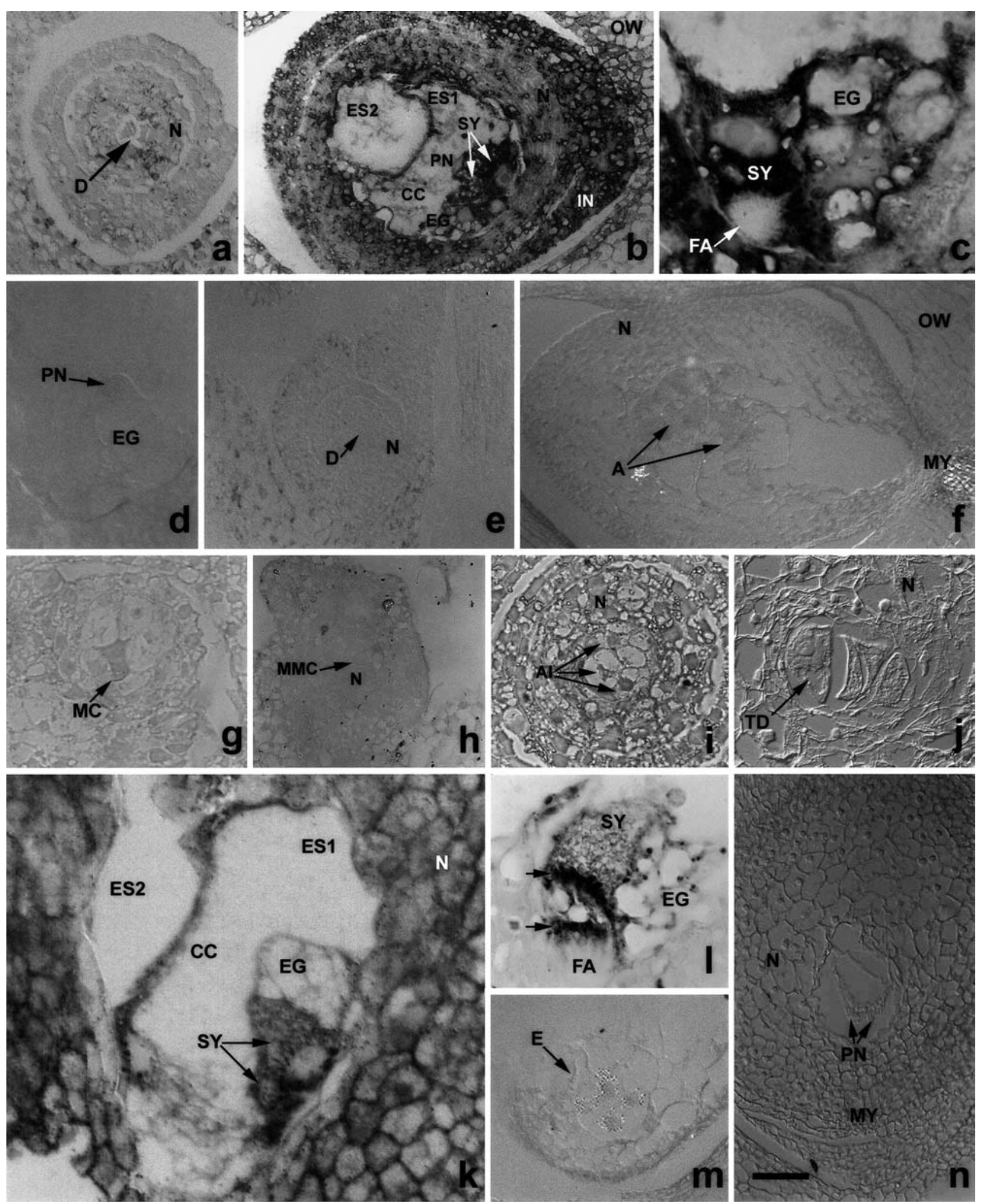
cell, and the nucellus. Following development, it was noted that first one synergid (Fig. 3f) and then all ES cells stopped expressing BbrizMYO (Fig. 3g). During sexual development, BbrizMYO signal was completely absent in the MMC (Fig. 3i), MC (Fig. 3j), and CO stages (Fig. 3k). However, it was present in the egg cell apparatus and nucellus of mature ES (Fig. 31, m) and was excluded from the embellum or central cell.

In apomictic plants, ovules lacked BbrizAQP signal in the MMC, MC (Fig. 4a), and AI. In ovules with a CO, signal was observed in the nucellus but not in micropylar cells. The integuments near the micropyle also displayed a signal that remained in the mature ES. In the mature ES, the cells from the egg apparatus showed high hybridization, and the central cell was also marked (Fig. 4b, c). In sexual plants, BbrizAQP transcripts were not detected at any stage of ES development, as shown in the dyad (Fig. 4e) and mature ES (Fig. 4f). Similarly, no BbrizMAPK hybridization was observed in ovules of sexual plants at any stage of development, as shown in the MMC (Fig. 4h), tetrads (Fig. 4j), and mature ES (Fig. 4n). In apomictic plants, no BbrizMAPK signal was detected in the MMC, MC, and AI (Fig. 4i). A weak signal could be observed in the cytoplasm of the $\mathrm{CO}$ and the nucellus. Transcripts could not be observed in integuments except in the micropylar pole. In young ES, all cells of the ovule showed hybridization, including the nucellus (Fig. 4k). Later, a strong signal was observed in the synergid near the filiform apparatus as well as in the cytoplasm (Fig. 41). The embellum did not show any signal. During anthesis and $48 \mathrm{~h}$ after pollination, when an embryo can be observed, transcripts could no longer be visualized (Fig. 4m).

\section{Discussion}

The analysis of in situ hybridizations suggested the participation of the three clones at different periods of ES development for aposporic apomictic and sexual B. brizantha. Only BbrizMYO was expressed in both types of ES, although it exhibited a timing delay in the Polygonum type of sexual plants. BbrizAQP and BbrizMAPK were expressed specifically in apomictic plants - BbrizAQP in cells of the ES and integuments and BbrizMAPK in different cells of the ovule, notably in synergids.

Synergids are very active cells of the ES, with dense cytoplasm and considerable amounts of nucleic acids and proteins (Tilton 1981). In plants in which fertilization occurs, they show a high number of endoplasmic reticulum cisternae and vesicles that are associated with ES maturation (Koscinska-Pajak and Bednara 2006). Synergids are important in pollen tube attraction and guidance during fertilization of higher plants (Jensen and Fisher 1968, Kapil and Bhatnagar 1975, Mogensen 1978, van Went and Willemse 1984, Russell 1992, Higashiyama 2002). Interestingly, in Chondrilla juncea, an obligate apomictic in which fertilization is not necessary for embryo or endosperm development, the synergids remain undifferentiated (Koscinska-Pajak and Bednara 2006). Nogler (1984) has previously suggested the existence of a state of balance between apomixis and sexuality that would favor apomixis during ES development and seed formation. Currently, it is thought that apomixis is a consequence of a rearrangement of the developmental programs that constitute the normal sexual pathway (Grimanelli et al. 2001, Koltunow and Grossniklaus 2003, Tucker et al. 2003).

Fig. 4. a-f Detection of BbrizAQP expression by in situ localization in semithin sections of ovules from apomictic (a-d) and sexual (e and f) $B$. brizantha plants. a Dyads $(D)$ enclosed by a nucellus $(N)$; bar: $6.2 \mu \mathrm{m}$. b Ovule with mature aposporic ES, showing strong signal in the egg cell $(E G)$, synergids $(S Y)$, central cell $(C C)$, polar nucleus $(P N)$ and integuments $(I N)$ near the micropyle, the ovary wall $(O W)$ showed no signal above background; bar: $9.1 \mu \mathrm{m}$. c Closer view of another section of the egg cell apparatus from the same ES as in b, showing detail of the hybridization in the cytoplasm of the synergids $(S Y)$ and egg cell $(E G)$; note that the filiform apparatus $(F A)$ lacks hybridization signal; bar: $2.9 \mu \mathrm{m}$. d Sense probe in apomictic ovule without label, with polar nucleus $(P N)$ and the egg cell $(E G)$; bar: $7.5 \mu \mathrm{m}$. e Ovary of sexual plant with dyads $(D)$ surrounded by a nucellus $(N)$ and no hybridization signal detected under our experimental conditions; bar: $8.9 \mu \mathrm{m}$. f Mature meiotic ES enclosed by a nucellus $(N)$, with antipodals $(A)$ opposite the micropylar pole $(M Y)$ and ovary wall $(O W)$, without visible hybridization signal; bar: $17 \mu m$. g-n Detection of BbrizMAPK expression by in situ localization in semithin sections of ovules from apomictic (g, i, k, l, and $\mathbf{m})$ and sexual (h, j, and $\mathbf{n})$ B. brizantha plants. $\mathbf{g}$ Hybridization of sense probe in an ovule from an apomictic plant showing no detectable hybridization signal in the $\mathrm{MC}$; bar: $6.0 \mu \mathrm{m}$. $\mathbf{h}$ Ovule of a sexual plant hybridized with the antisense probe showing no hybridization signal in either the MMC or the nucellus $(N)$; bar: $6.7 \mu \mathrm{m}$. i AI in the nucellus $(N)$ showing no hybridization signal; bar: $6.7 \mu \mathrm{m}$. $\mathbf{j}$ Ovule of a sexual plant with megaspore tetrads $(T D)$ enveloped by nucellus $(N)$ showing no hybridization label; bar: $7.2 \mu \mathrm{m}$. k Micropylar region of an immature ovule containing two ES (ES1 and ES2) showing hybridization signal in all cells, including the central cell $(C C)$, egg cell $(E G)$ and both of the synergids $(S Y)$ strongly marked on the micropylar portion. The nucellus cells $(N)$ show a signal similar to that of ES cells; bar: $4.4 \mu \mathrm{m}$. I Micropylar region of a mature ovule with a strong transcript signal confined to the synergids $(S Y)$, principally in the cytoplasmic region (arrow) near the filiform apparatus (FA), but also on the egg cell (EG); bar: $4.2 \mu \mathrm{m}$. $\mathbf{m}$ Micropylar side of an ovule containing an autonomous embryo $(E) 48 \mathrm{~h}$ after fertilization without any label; bar: $15.8 \mu \mathrm{m}$. n Ovule of a sexual plant containing ES with two polar nuclei $(P N)$ surrounded by nucellus $(N)$ without any hybridization signal, as observed under the experimental conditions used; bar: $10.5 \mu \mathrm{m}$ 
Using differences in the morphology of the ovule and the ES during development, it is possible to recognize specific points in the pathway that lead to the formation of a meiotic or aposporic ES. One point is related to the failure of meiosis and differentiation of AI. Although meiosis seems to be complete in apomictic $B$. brizantha ovules (Araujo et al. 2000), all four megaspores degenerate, instead of the three in meiotic development, and many AI appear. It has been suggested that the development of AI might directly influence the failure of the sexual program by a modification in gene expression, but the molecular identity of these cells and the relationship between the meiotic and aposporic pathways are still unknown (Tucker et al. 2003). Another point is the autonomous development of the embryo that normally occurs only in apomictic plants. In Brachiaria species, embryogenesis has been found even before fertilization (Dusi and Willemse 1999a, Araujo et al. 2000). This means that autonomous egg cell development is independent of pollination or central cell fertilization.

In this work, the expression patterns of BbrizMYO, $B b r i z A Q P$, and BbrizMAPK in meiotic and aposporic pathways were correlated to the functions suggested by their molecular identity.

In general, myosin works by interacting with actins to supply the motile force for many cell movements (Alberts et al. 1994, Lodish et al. 2001). In plants, myosin is involved in the cytoplasmic cell or symplast streaming that creates cytoplasmic reorganization during cell reproduction (reviewed by Shimmen and Yokota 2004). The expression of BbrizMYO in apomictic ovaries, apart from the nucellus, was detected in two stages of ovule development. Initially, expression was found in the MC, before cell division, when the cell is enlarging and a cytoplasmic rearrangement is leading to polarized cells. Later, BbrizMYO transcripts were detected in the egg apparatus and central cell, at the same time as these cells position themselves with respect to each other. The expression was very strong in the egg apparatus, especially in the synergids, and was also observed in sexual ovules. Cytoskeletal elements within and between cells are considered to participate in the events of fertilization, sperm cell guidance, and migration of the male nuclei (Russell 1993). In fact, in apomictic and sexual $B$. brizantha plants, both events occur once apomixis is pseudogamic, and in the apomict, one sperm cell is necessary to form the endosperm (Alves et al. 2001). Actin filaments have been observed in the egg and central cells of Torenia fournieri in a radial arrangement and were abundant near the filiform apparatus and in one of the synergids in particular ( $\mathrm{Fu}$ et al. 2000). Extending this to
B. brizantha, the putative site of actin filaments would be coincident with the localization of BbrizMYO transcripts. On the other hand, in meiotic ES, the cells are distributed at both poles, and BbrizMYO is also clearly polarized to the chalazal and micropylar sides. When the ES was already organized, BbrizMYO transcripts were totally absent, and expression was restricted to the nucellus cells. At the same time, the ES was being prepared for fertilization. In the apomictic $B$. brizantha cv. Marandu, the degeneration of one of the synergids is associated with pollen tube discharge inside the ES (Alves 2000). BbrizMYO expression, which was formerly detected in both synergids of this same plant, was arrested in one before the other, as is also observed in sexual plants. BbrizMYO transcripts were never detected in the $\mathrm{CO}$, a stage of ES development in which karyokinesis repeatedly occurs, in accordance with observations that intact myosin is necessary for cytokinesis but not for karyokinesis (Yumura et al. 1984, De Lozanne and Spudich 1987, Solomon 1987, Lodish et al. 2001).

The expression of BbrizAQP in $B$. brizantha was restricted to ovaries containing young and mature ES from apomictic accession. Aquaporins control the osmotic flow of water across the plasma membrane (Lodish et al. 2001). In plants, aquaporins play a role in protein transport into or out of the protein bodies during seed development and germination (Chrispeels and Maurel 1994), and they may have a role in the development of caryopsis in B. brizantha. The absence of transcripts in the nucellus and their presence in integuments are also consistent with the fate of these tissues, since the nucellus will degenerate and the integument will start differentiation. Since no expression of BbrizAQP could be detected in sexual $B$. brizantha ovules by our method of choice, it must be involved in events unique to the apomictic plants. In fact, reports of tissue-specific expression of aquaporins in plants are frequent (Chaumont et al. 2001, Ciavatta et al. 2001, Hakman and Oliviusson 2002). Aquaporins seem to be preferentially expressed in cells with high metabolic activity (Barrieu et al. 1998) such as the synergids (Tilton 1981). This could explain the high expression of BbrizAQP found not only in egg cells but especially in synergids.

Big Brain protein (BIB) from Drosophila species shows identity to aquaporins of different origins, according to the National Center for Biotechnology Information (www.ncbi. nlm.nih.gov), and an amino acid identity of up to $61 \%$ was verified between the BIB gi|33637920 from Drosophila americana and the aquaporin gi|108879624| from Aedes aegypti. BIB contains a large C-terminal domain with many putative consensus sites for kinase-mediated modulation 
(Burris et al. 1998, Yanochko and Yool 2002). BIB expression in Xenopus laevis oocytes suggests that activation in vivo would result in membrane depolarization that could then trigger parthenogenesis by kinases that are involved in intracellular signaling pathway (Wolf 1974, Yanochko and Yool 2002). By association, it is possible that BbrizAQP expression in the mature ES of apomictic plants, but not in sexual plants, could be indicative of its involvement in the autonomous development in B. brizantha. The unreduced egg cell will not have a resting period and instead, by means of a continuous nutrient supply, will develop into an embryo. The higher expression signal of BbrizAQP observed in the egg apparatus of the ES, mainly in the synergids, could be related to the attributed function of the synergids in the attraction and reception of the pollen tube during fertilization (van Went 1970, Friedman 2006, Koscinska-Pajak and Bednara 2006). Expression was remarkable during aposporic ES maturation and is probably related to embryo development and central cell fertilization. In B. brizantha apomicts, fertilization is restricted to the central cell, which forms the endosperm (Alves et al. 2001); therefore, there is a need to attract one sperm cell to the central cell while preventing the other sperm cell from fertilizing the egg cell that develops autonomously. In addition, it has already been reported that phosphorylation increases the activity of aquaporins in plants (Chrispeels et al. 1999), and our in situ hybridization results showed a significant expression of BbrizMAPK in the synergids of mature aposporic ES, mainly in the micropylar region.

Mitogen-activated protein kinase (MAPK) is involved in signaling in eukaryotic cells. In Saccharomyces cerevisiae, these processes include mating, maintenance of cell wall integrity, and spore formation (Herskowitz 1995). In animals, MAPK plays an important role in mitosis and growth factor-stimulated signaling. In plants, it participates in growth, hormone action, and dynamics of the cytoskeleton (Heberle-Bors 2001). BbrizMAPK expression, besides its presence in the nucellus, seems to be particularly high in synergids of apomictic $B$. brizantha. After fertilization, it was no longer detected under our experimental conditions. Different levels of MAPK cDNA have been found in distinct organs of Medicago sativa and are dependent on the phase of the cell cycle (Jonak et al. 1993). $M A P K$ transcripts have also been detected during the development of reproductive floral organs of Petunia hybrida (Decroocq-Ferrant et al. 1995). The presence of BbrizMAPK transcripts in synergids and their absence in ES after fertilization, and in autonomously developed embryos, indicate that it might have a role in events related to the maturation of the ES, preparing it for fertilization and the beginning of embryo development.

The aim of this work was to characterize the expression of cDNA sequences isolated at specific stages of pistil development before anthesis of apomictic plants, in order to determine in situ their role in the events characteristic of this reproductive pathway. The three cDNA sequences have been previously associated with ovary development by reverse Northern analysis. The in situ hybridization analyses indicated that the synergids were the main site of modulation of their expression during ES development, suggesting their involvement in ES maturation, fertilization, and embryogenesis. Differences in each of these events in apomicts from their equivalents in sexual plants are directly related to autonomous embryo development, a characteristic of apomicts. Therefore, synergids may play a crucial role, not only in the moment of fertilization but also in the autonomous development of the unreduced egg cell, typical of apomictic plants. The BbrizMYO, BbrizAQP, and $B b r i z M A P K$ expression profiles in synergids described herein may be the first step towards understanding the molecular pattern of gene expression in these natural apomictic plants.

\section{Acknowledgments}

This work was partially supported by the CBAB/MCT (Ministry of Science and Technology, Brazil). We thank M. T. M. Willemse for his critical review of this manuscript and A. C. M. M. Gomes for technical assistance. E. R. Alves thanks CAPES (Brazilian Education Ministry) and CNPq (National Council for Scientific and Technological Development, Brazil) for a partial $\mathrm{PhD}$ scholarship.

\section{References}

Albertini E, Marconi G, Barcaccia G, Raggi L, Falcinelli M (2004) Isolation of candidate genes for apomixis in Poa pratensis L. Plant Mol Biol 56: 879-894

Albertini E, Marconi G, Reale L, Barcaccia G, Porceddu A, Ferranti F, Falcinelli M (2005) SERK and APOSTART. Candidate genes for apomixis in Poa pratensis. Plant Physiol 138: 2185-2199

Alberts B, Bray D, Lewis J, Raff M, Roberts K, Watson JD (1994) Biologia molecular da célula, 3rd edn. Artes Médicas, Porto Alegre

Alves ER (2000) Aspectos da reprodução em Brachiaria brizantha cv. Marandu. Mestrado em Botânica, Universidade de Brasília, Brasília, Brazil

Alves ER, Carneiro VTC, Araujo ACG (2001) Direct evidence of pseudogamy in an apomictic Brachiaria brizantha (Poaceae). Sex Plant Reprod 14: 207-212

Araujo ACG, Mukhambetzhanov S, Pozzobon MT, Santana EF, Carneiro VTC (2000) Female gametophyte development in apomictic and sexual Brachiaria brizantha (Poaceae). Rev Cytol Biol Veg 23: 13-28

Asker SE, Jerling L (1992) Apomixis in plants. CRC Press, Boca Raton, Fla

Barrieu F, Chaumont F, Chrispeels MJ (1998) High expression of the tonoplast aquaporin ZmTIP1 in epidermal and conducting tissues of maize 1. Plant Physiol 117: 1153-1163 
Burris PA, Zhang Y, Rusconi JC, Corbin V (1998) The pore-forming and cytoplasmic domains of the neurogenic gene product, BIG BRAIN, are conserved between Drosophila virilis and Drosophila melanogaster. Gene 206: 69-76

Carman JG (1997) Asynchronous expression of duplicate genes in angiosperms may cause apomixis, bispory, tetraspory, and polyembryony. Biol J Linn Soc 61: 51-94

Chaumont F, Barrieu F, Wojcik E, Chrispeels MJ, Jung R (2001) Aquaporins constitute a large and highly divergent protein family in maize. Plant Physiol 125: 1206-1215

Chen L, Miyazaki C, Kojima A, Saito A, Adachi T (1999) Isolation and characterization of a gene expressed during early embryo sac development in apomictic guinea grass (Panicum maximum). J Plant Physiol 154: 55-62

Chen L, Guan L, Seo M, Hoffmann F, Adachi T (2005) Developmental expression of ASG-1 during gametogenesis in apomictic guinea grass (Panicum maximum). J Plant Physiol 162: 1141-1148

Chrispeels MJ, Maurel C (1994) Aquaporins: the molecular basis of facilitated water movement through living plant cells? Plant Physiol 105: 9-13

Chrispeels MJ, Crawford NM, Schroeder JI (1999) Proteins for transport of water and mineral nutrients across the membranes of plant cells. Plant Cell 11: 661-675

Ciavatta VT, Morillon R, Pullman GS, Chrispeels MJ, Cairney J (2001) An aquaglyceroporin is abundantly expressed early in the development of the suspensor and the embryo proper of loblolly pine. Plant Physiol 127: 1556-1567

De Lozanne A, Spudich JA (1987) Disruption of the Dictyostelium myosin heavy chain gene by homologous recombination. Science 236 : 1086-1091

Decroocq-Ferrant V, van Went J, Bianchi MW, De Vries SC, Kreis M (1995) Petunia hybrida homologues of shaggy/zeste-white 3 expressed in female and male reproductive organs. Plant J 7: 897-911

do Valle CB (1986) Cytology, mode of reproduction and forage quality of selected species of Brachiaria Griseb. $\mathrm{PhD}$ thesis, University of Illinois, Urbana, Ill

do Valle CB, Savidan Y (1996) Genetics, cytogenetics and reproductive biology of Brachiaria. In: Miles JW, Maass BL, do Valle CB (eds) Brachiaria: biology, agronomy and improvement. Centro Internacional de Agrocultura Tropical and Empresa Brasileira de Pesquisa Agropecuária, Cali, Colombia and Campo Grande, Brazil, pp 147-163

Dusi DMA (2001) Apomixis in Brachiaria decumbens Stapf. PhD thesis, University of Wageningen, Wageningen, the Netherlands

Dusi DMA, Willemse MTM (1999a) Activity and localisation of sucrose synthase and invertase in ovules of sexual and apomictic Brachiaria decumbens. Protoplasma 208: 173-185

Dusi DMA, Willemse MTM (1999b) Apomixis in Brachiaria decumbens Stapf.: gametophytic development and reproductive calendar. Acta Biol Cracov Ser Bot 41: 151-162

Fisher MJ, Kerridge PC (1996) The agronomy and physiology of Brachiaria species. In: Miles JW, Maass BL, do Valle CB (eds) Brachiaria: biology, agronomy and improvement. Centro Internacional de Agricultura Tropical and Empresa Brasileira de Pesquisa Agropecuária, Cali, Colombia and Campo Grande, Brazil, pp 43-52

Friedman WE (2006) Embryological evidence for developmental lability during early angiosperm evolution. Nature 441: 337-340

Fu Y, Yuan M, Huang BQ, Yang HY, Zee SY, O’Brien TP (2000) Changes in actin organization in the living egg apparatus of Torenia fournieri during fertilization. Sex Plant Reprod 12: 315-322

Grimanelli D, Leblanc O, Perotti E, Grossniklaus U (2001) Developmental genetics of gametophytic apomixis. Trends Genet 17: 597-604

Hakman I, Oliviusson P (2002) High expression of putative aquaporin genes in cells with transporting and nutritive functions during seed development in Norway spruce (Picea abies). J Exp Bot 53: 639-649
Hanna WW, Bashaw EC (1987) Apomixis: its identification and use in plant breeding. Crop Sci 27: 1136-1139

Heberle-Bors E (2001) Cyclin-dependent protein kinases, mitogen-activated protein kinases and the plant cell cycle. Curr Sci 80: 225-232

Herskowitz I (1995) MAP kinase pathways in yeast: for mating and more. Cell 80: 187-197

Higashiyama T (2002) The synergid cell: attractor and acceptor of the pollen tube for double fertilization. J Plant Res 115: 149-160

Jensen WA, Fisher DB (1968) Cotton embryogenesis: entrance and discharge of the pollen tube in the embryo sac. Planta 78: 158-183

Jonak C, Páy A, Bögre L, Hirt H, Heberle-Bors E (1993) The plant homologue of MAP kinase is expressed in a cell cycle-dependent and organ-specific manner. Plant J 3: 611-617

Kapil RN, Bhatnagar AK (1975) A fresh look at the process of double fertilization in angiosperms. Phytomorphology Silver Jubilee: 334-368

Koltunow AM, Grossniklaus U (2003) Apomixis: a developmental perspective. Annu Rev Plant Biol 54: 547-574

Koscinska-Pajak M, Bednara J (2006) Unusual microtubular cytoskeleton of apomictic embryo sac of Chondrilla juncea L. Protoplasma 227: 87-93

Leblanc O, Armstead I, Pessino S, Ortiz JPA, Evans C, do Valle CB, Hayward MD (1997) Non-radioactive mRNA fingerprinting to visualize gene expression in mature ovaries of Brachiaria hybrids derived from B. brizantha, an apomictic tropical forage. Plant Sci 126: 49-58

Lodish H, Berk A, Zipursky SL, Matsudaira P, Baltimore D, Darnell JE (2001) Molecular cell biology, 4th edn. WH Freeman and Company, New York

Lutts S, Ndikumana J, Louant BP (1994) Male and female sporogenesis and gametogenesis in apomictic Brachiaria brizantha, Brachiaria decumbens and $\mathrm{F}_{1}$ hybrids with sexual colchicine induced tetraploid Brachiaria ruziziensis. Euphytica 78: 19-25

Miles JW, Maass BL, do Valle CB (eds) (1996) Brachiaria: biology, agronomy and improvement. Centro Internacional de Agricultura Tropical and Empresa Brasileira de Pesquisa Agropecuária, Cali, Colombia and Campo Grande, Brazil

Mogensen HL (1978) Pollen tube-synergid interactions in Proboscidea louisianica (Martineaceae). Am J Bot 65: 953-964

Ngendahayo M (1988) Méchanismes de la reproduction dans le genre Brachiaria. PhD thesis, Université Catholique de Louvain, Louvain, Belgium

Nogler GA (1984) Gametophytic apomixis. In: Johri BM (ed) Embryology of angiosperms. Springer, Berlin Heidelberg New York, pp 475-518

Nogler GA (1994) Genetics of gametophytic apomixis - a historical sketch. Pol Bot Stud 8: 5-11

Penteado MIO, Santos ACM, Rodrigues IF, do Valle CB, Seixas MAC, Esteves A (2000) Determinação de ploidia e avaliação da quantidade de DNA total em diferentes espécies do gênero Brachiaria. Embrapa Gado de Corte, Boletim de Pesquisa, vol 11. Empresa Brasileira de Pesquisa Agropecuária Gado de Corte, Campo Grande, Brazil

Pessino SC, Espinoza F, Martinez EJ, Ortiz JP, Valle EM, Quarin CL (2001) Isolation of cDNA clones differentially expressed in flowers of apomictic and sexual Paspalum notatum. Hereditas 134: 35-42

Rodrigues JCM, Cabral GB, Dusi DMA, Mello LV, Rigden D, Carneiro VTC (2003) Identification of differentially expressed cDNA sequences in ovaries of sexual and apomictic plants of Brachiaria brizantha. Plant Mol Biol 53: 745-757

Russell SD (1992) Double fertilization. In: Russell SD, Dumas C (eds) Sexual reproduction in flowering plants. International review of cytology, vol 140. Academic Press, London, pp 357-388

Russell SD (1993) The egg cell: development and role in fertilization and early embryogenesis. Plant Cell 5: 1349-1359

Serrão EAD, Simão Neto M (1971) Informações sobre duas espécies de gramíneas forrageiras do gênero Brachiaria na Amazônia: B. decumbens Stapf e B. ruziziensis Germain et Evrard. Estudos sobre forrageiras 
na Amazônia, vol 2, nr 1. Instituto de Pesquisae Experimentação Agropecuária do Norte, Belém, Brazil

Shimmen T, Yokota E (2004) Cytoplasmic streaming in plants. Curr Opin Cell Biol 16: 68-72

Solomon F (1987) What myosin might do. Science 236: 1043-1044

Tilton VR (1981) Ovule development in Ornithogalum caudatum (Liliaceae) with a review of selected papers on angiosperm reproduction. IV. Egg apparatus structure and function. New Phytol 88: 505-531

Tucker MR, Araujo ACG, Paech N, Hecht V, Schmidt EDL, Rossel J-B, De Vries SC, Koltunow AMG (2003) Sexual and apomictic reproduction in Hieracium subgenus Pilosella are closely interrelated developmental pathways. Plant Cell 15: 1524-1537

van Went JL (1970) The ultrastructure of the synergids of Petunia. Acta Bot Neerl 19: 121-132 van Went JL, Willemse MTM (1984) Fertilization. In: Johri BM (ed) Embryology of angiosperms. Springer, Berlin Heidelberg New York, pp 273-317

Vielle-Calzada J-P, Nuccio ML, Budiman MA, Thomas TL, Burson BL, Hussey MA, Wing RA (1996) Comparative gene expression in sexual and apomictic ovaries of Pennisetum ciliari (L.) Link. Plant Mol Biol 32: 1085-1092

Wolf DP (1974) The cortical response in Xenopus laevis ova. Dev Biol 40: $102-115$

Yanochko GM, Yool AJ (2002) Regulated cationic channel function in Xenopus oocytes expressing Drosophila Big Brain. J Neurosci 22: 2530-2540

Yumura S, Mori H, Fukui Y (1984) Localization of actin and myosin for the study of ameboid movement in Dictyostelium using improved immunofluorescence. J Cell Biol 99: 894-899 